\title{
Comparison of Macular and Retinal Nerve Fiber Layer Thickness in Amblyopic and Fellow Eyes
}

\section{Ambliyopik ve Sağlam Gözlerde Maküler ve Retinal Sinir Lifi Tabakası Kalınlığının Karşılaştırılması}

\section{Ceren Gürez (1)}

University of Health Sciences Beyoglu Eye Research and Training Hospital, Istanbul, Turkey

Received: 30.04.2020 / Accepted: 20.01.2021 / Published Online: 31.03.2021

Cite as: Gürez C. Comparison of macular and retinal nerve fiber layer thickness in amblyopic and fellow eyes. Med J Bakirkoy 2021;17(1):36-40.

\section{ABSTRACT}

Objective: The purpose of this study is to investigate the relationship between macular and peripapillary retinal nerve fiber layer thickness and amblyopia.

Methods: A total of 56 pediatric patients with hyperopic anisometropic amblyopia were evaluated in this study. As the control group, we used the patients' fellow eyes. A comprehensive eye examination was performed, including best-corrected visual acuity with Snellen charts (converted to logMAR for analysis), slit-lamp examination, fundus examination, cover and, cover-uncover testing, and ocular motility testing. The macular thickness, retinal nerve fiber layer thickness, axial length and optic disc area of both eyes were measured.

Results: The mean age was $7.25 \pm 1.89$ years. For the amblyopic and fellow eyes, the mean best-corrected visual acuity was $0.33 \pm 0.20$ logMAR and $0.0 \pm 0.0 \log M A R$, respectively. Macular center thicknesses were 225,55 $\pm 18,86 \mu \mathrm{m}$ and $215,7 \pm 12,96 \mu \mathrm{m}$ in amblyopic and fellow eyes, respectively. Macular $6 \mathrm{~mm}$ ring thicknesses were $281,32 \pm 33,51 \mu \mathrm{m}$ and $256,07 \pm 28,91 \mu \mathrm{m}$ in amblyopic and fellow eyes, respectively. RNFLT

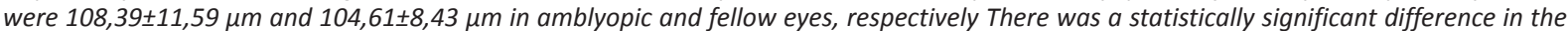
macular center thickness, in macular 6-mm ring area thickness and in RNFLT $(p<0.05)$. There was a positive correlation between visual acuity of amblyopic eyes and macular thickness and RNFLT.

Conclusions: This study explored objectively measured retinal changes in amblyopia and found a slightly thicker central macular region and 6-mm ring area thicknesses and RNFLT in amblyopic compared with normal eyes.

Keywords: amblyopia, macular thickness, retinal nerve fiber layer

öz

Amaç: Bu çalışmanın amacı maküler ve peripapiller retina sinir lifi tabakası kalınlığı ile ambliyopi arasındaki ilişkiyi araştırmak. Gereç-Yöntem: Bu çalışmada hipermetropik anizometropik ambliyopisi olan toplam 56 çocuk hasta değerlendirildi. Kontrol grubu olarak hastaların sağlam gözleri kullanıldı. Snellen eşeli (analiz için logMAR'a dönüştürülmüş) ile en iyi düzeltilmiş görme keskinliği, yarık lamba muayenesi, fundus muayenesi, örtme ve örtme-açma testi ve göz hareketleri dahil olmak üzere kapsamlı göz muayenesi yapıldı. Her iki gözün maküler kalınlığı, retinal sinir lifi tabakası kalınlığı(RNFLT), aksiyel uzunluğu ve optik disk çapı ölçüldü.

Bulgular: Ortalama yaș $7.25 \pm 1.89$ yıl idi. Ambliyopik ve sağlam gözler için ortalama en iyi düzeltilmiş görme keskinliği sırasıyla $0.33 \pm 0.20$ logMAR ve $0.0 \pm 0.0$ logMAR idi. Makula merkez kalınlıkları ambliyopik ve sağlam gözlerde sırasıyla 225,55 $\pm 18,86 \mu \mathrm{m}$ ve $215,7 \pm 12,96 \mu \mathrm{m}$

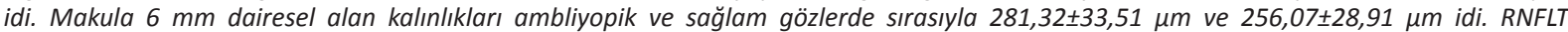
ambliyopik ve sağlam gözlerde sırasıyla 108,39 $\pm 11,59 \mu \mathrm{m}$ ve 104,61 $\pm 8,43 \mu \mathrm{m}$ idi. Maküler merkez kalınlığında, maküler 6 mm dairesel alan kalınlığında ve RNFLT'de ambliyopik ve sağlam göz arasında istatistiksel anlamlı farklıık saptandı(p<0.05). Ambliyopik gözlerin görme keskinliği ile maküler kalınlık ve RNFLT arasında pozitif korelasyon vardı.

Sonuçlar: Bu çalışmada ambliyopide objektif olarak ölçülen retina değişiklikleri araştırıldı ve maküler kalınlık ve RNFLT normal gözlere göre ambliyopik gözlerde daha kalın bulundu.

Anahtar kelimeler: amliyopi, maküler kalınlık, retina sinir lifi tabakası 


\section{INTRODUCTION}

Amblyopia is reduced best-corrected visual acuity in one or both eyes caused by abnormal visual experience during visual development. Causes of amblyopia are strabismus, anisometropia, and form-vision deprivation. ${ }^{1}$ Each of these has functional and morphologic effects on the visual cortex and lateral geniculate nucleus. ${ }^{2}$ Although amblyopia is associated with a structurally normal eye, several studies have reported visual field abnormalities and anatomical changes in visual pathways of amblyopic patients. ${ }^{3-6}$ It has been hypothesized that amblyopia may affect the postnatal maturation of the retina, including the postnatal reduction of retinal ganglion cells, which would lead to a measurable increase in retinal nerve fiber layer thickness (RNFLT) in amblyopic eyes. ${ }^{7}$ Some investigators have found an increased RNFLT in amblyopic eyes, whereas others have found no significant differences. ${ }^{8-11}$ Studies of macular thickness have also produced discordant results. ${ }^{12-16}$

This study examined the relationship between macular and peripapillary RNFL thickness and amblyopia of children aged 4 and 13 years.

\section{SUBJECT AND METHODS}

This study was conducted in accordance with the principles of the Declaration of Helsinki and approved by the Bagcilar Training and Research Hospital Clinical Research Ethics Committee. Written informed consent was obtained from the parents or legal guardian of each patient following a detailed explanation of the study objectives and protocol. A total of 56 pediatric patients(20 females, 36 males), which followed up at Health of Sciences University Bagcilar Training and Research Hospital Eye Clinic, with hyperopic anisometropic amblyopia were evaluated in this study. They were still in patching treatment for amblyopia. As the control group, we used the patients' fellow eyes. Inclusion criteria were the presence of unilateral amblyopia due to hyperopic anisometropia for the children in the amblyopia group. Presence of strabismus, nystagmus, deprivation amblyopia, history of previous ocular surgery, intraocular inflammation, corneal disease, retinal disease or optic nerve disease, ocular media opacities, including cataract or other diseases of the visual pathway, glaucoma, neurological disease, and insuffi- cient cooperation were exclusion criteria. All refractive errors were converted to spherical equivalent values. Anisometropia was defined as a 1.50 diopter(D) difference between two eyes. Unilateral amblyopia was defined as best-corrected visual acuity of 0.20 LogMAR or worse in one eye and at least a 2-line difference between the amblyopic eye and the fellow eye.

\section{Study Parameters}

A comprehensive eye examination was performed, including best-corrected visual acuity with Snellen charts (converted to logMAR for analysis), slit-lamp examination, fundus examination, cover and, coveruncover testing, and ocular motility testing. Three drops of cyclopentolate hydrochloride $1 \%$ were administered 5 minutes apart, and autorefraction was performed using an automatic refractor-keratometer device (Canon, Tokyo, Japan) approximately 45 minutes after the last drop.

\section{Imaging}

Optical coherence tomography (Nidek RS-3000) was performed through dilated pupils to obtain cross-sectional measurements of the retina. This instrument used partial coherence interferometry technology to obtain optical A-scans of the retina. Retinal boundaries used to make these measurements were identified by changes in reflectivity associated with these interfaces. This instrument has an axial resolution of approximately 10 micrometers $(\mu \mathrm{m}) .^{17-21}$ Peripapillary RNFL thickness was measured using the "fast RNFL thickness" scan protocol. This comprised 256 sampling points along a circular scan path. Three scans were performed, and the average was used in analyses. This is a measure of the total cross-sectional area of ganglion cell axons converging toward the optic disc. Macular thickness was measured as the distance between the internal limiting membrane and the retinal pigment epithelium using the "fast macular scan" protocol. The macular retinal thickness of both eyes at the center and 1-, 3-, and 6-mm rings in different segments (superior, inferior, nasal, and temporal) were measured. An average of 5 scans was used in the analysis. A single experienced operator performed all scans.

\section{Statistical Analysis}

In this study, statistical analysis was done by the NCSS (Number Cruncher Statistical System) 2007 Statistical Software (Utah, USA) pocket program. In 
the evaluation of data, repeated statistical methods (mean, standard deviation) as well as paired t-test for comparison of amblyopic and fellow eyes, variance analysis of multiple groups, Pearson correlation test for the relationship between variables, were used. The results were evaluated at $p<0.05$ level.

\section{RESULTS}

The mean age was $7,25 \pm 1,89$ years ( $4-13$ years). For the amblyopic and fellow eyes, the mean best-corrected visual acuity was $0,33 \pm 0,20 \log M A R$ an, $0,0 \pm$ $0,0 \log M A R$, the mean spherical equivalent refraction was $5,27 \pm 1,39$ and $1,09 \pm 0,69 \mathrm{D}$, and the mean axial length were $21,4 \pm 0,71$ and $22,1 \pm 0,37 \mathrm{~mm}$ respectively $(p<0,05)$. Macular center thicknesses were $225,55 \pm 18,86 \mu \mathrm{m}$ and $215,7 \pm 12,96 \mu \mathrm{m}$ in amblyopic and fellow eyes, respectively $(p<0,05)$. Macular $6 \mathrm{~mm}$ ring thicknesses were $281,32 \pm 33,51$ $\mu \mathrm{m}$ and $256,07 \pm 28,91 \mu \mathrm{m}$ in amblyopic and fellow eyes, respectively $(p<0,05)$. RNFLT were108,39 $\pm 11,59$ $\mu \mathrm{m}$ and $104,61 \pm 8,43 \mu \mathrm{m}$ in amblyopic and fellow eyes, respectively $(p<0,05)$. Optic disc area were $2,68 \pm 0.83 \mathrm{~mm}$ and $2,90 \pm 0,69 \mathrm{~mm}$ in amblyopic and fellow eyes, respectively $(p<0,05)$. There was a statistically significant difference in the macular center thickness, in macular 6-mm ring area thickness and, $\operatorname{RNFLT}(p<0,05)$ (Table 1). There was a positive correlation between spherical equivalence of amblyopic eyes and macular thickness, RNFLT, and optic disc area; and a negative correlation between axial length.

\section{DISCUSSION}

In our study, we found statistically significant differences in macular thickness between amblyopic and non-amblyopic eyes, as measured by optical coherence tomography. Macular thickness was greater (by $\sim 10 \mu \mathrm{m}$ ) in the amblyopic than the normal fellow eye $(p<0.05)$. Huynh et a ${ }^{12}$ compared macular thickness between amblyopic and normal fellow eyes of 4118 children in a population-based study and found that macular thickness was 5-10 $\mu \mathrm{m}$ greater in amblyopic eyes. Altindag et $\mathrm{al}^{13}$ also found that the macular thickness was significantly higher in strabismic amblyopic cases compared to the controls, similar to our study. Altintas et $\mathrm{al}^{10}$ found no differences in macular thickness between amblyopic and normal eyes. Rajavi et $\mathrm{al}^{15}$ found a significant difference in

\begin{tabular}{|l|c|c|c|}
\hline & Amblyopic Eye & Fellow Eye & $\boldsymbol{p}$ \\
\hline VA(logMar) & $0,33 \pm 0,20$ & $0,0 \pm 0$ & $\mathbf{0 , 0 0 0 1}$ \\
\hline $\begin{array}{l}\text { Macula } \\
\text { center } \\
\text { (micron) }\end{array}$ & $225,55 \pm 18,86$ & $215,7 \pm 12,96$ & $\mathbf{0 , 0 0 0 1}$ \\
\hline $\begin{array}{l}\text { Macula 6-mm } \\
\text { ring area } \\
\text { (micron) }\end{array}$ & $281,32 \pm 33,51$ & $256,07 \pm 28,91$ & $\mathbf{0 , 0 0 0 1}$ \\
\hline $\begin{array}{l}\text { RNLFT } \\
\text { (micron) }\end{array}$ & $108,39 \pm 11,59$ & $104,61 \pm 8,43$ & $\mathbf{0 , 0 0 4}$ \\
\hline \begin{tabular}{l} 
AxL (mm) \\
\hline $\begin{array}{l}\text { Optic Disc } \\
\text { Area (mm) }\end{array}$
\end{tabular} & $21,4 \pm 0,71$ & $22,1 \pm 0,37$ & $\mathbf{0 , 0 1}$ \\
\hline
\end{tabular}

Values are presented as mean \pm standard deviation

VA:Visual Acuity, mm:milimeter, RNFLT: Retinal Nerve Fiber Layer Thickness, AxL: Axial Length

Table 1: Comparison of amblyopic eye and fellow eye for Visual Acuity, Macula center thickness, Macula 6-mm area thickness, RNFLT, Axial Length, and Optic Disc Area

macular retinal thickness at the center and 1-mm ring area in the moderately to severely amblyopic eyes compared to the non-amblyopic controls, whereas this difference was not observed at the 3and $6-\mathrm{mm}$ rings. We found in the macular center and also in the 6-mm ring area statistically significant differences. Liu et $a^{22}$ measured a mean retinal thickness of $201.5 \pm 17.9$ and $176.7 \pm 14.8 \mu \mathrm{m}$ at the central and foveal areas in refractory amblyopic eyes, respectively, and they also found a significant difference when compared with normal Chinese children. Andalib et $\mathrm{al}^{23}$ reported a significantly higher macular thickness in anisometropic amblyopic cases, though they did not find the same result in strabismic amblyopic cases. Doguizi et al ${ }^{24}$ reported too significantly higher central macular thickness in amblyopic eyes than in fellow and control

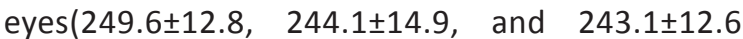
respectively), but they found no significant difference between groups in terms of inner and outer macular thickness. Taşkıran-Çömez et al did not found in macular thickness significant difference in their series including myopic and hyperopic amblyopic children.

In the present study, we found RNFLT was $\sim 4 \mathrm{~m}$ thicker in amblyopic eyes, and that was statistically a significant difference $(p<0.05)$. Repka et al ${ }^{11}$ found that amblyopic eyes have $\sim 7 \mu \mathrm{m}$ greater thickness for RNFLT. Altintas et al ${ }^{10}$ found RNFLT $2.5 \mu \mathrm{m}$ thicker in amblyopic eyes, and that was not significant in their 
study. Bozkurt et a ${ }^{25}$ also used a scanning laser polarimeter to examine 24 children with anisometropic amblyopia and found no difference in all parameters. Colen et $\mathrm{al}^{26}$, using a scanning laser polarimeter, reported similar findings in 20 subjects with unilateral strabismic amblyopia. Baddini-Caramelli et al ${ }^{27}$, using a scanning laser polarimeter in 21 children with unilateral amblyopia, found that the RNFLT may be thicker in amblyopic eyes. Yen et $\mathrm{al}^{7}$, examined 38 children with unilateral amblyopia (20 strabismic, 18 refractive) and found that children with refractive amblyopia had significantly greater average RNFLT in the amblyopic eye than the normal fellow eye, but no differences were found in children with unilateral strabismic amblyopia. Yoon et $\mathrm{al}^{28}$, found that children with anisometropic amblyopia had greater average RNFLT in their amblyopic eyes than normal fellow eyes. Taşkıran-Çömez et al ${ }^{29}$ did not found in RNFLT significant difference in their series including myopic and hyperopic amblyopic children.

The optic disc area is directly associated with the number of nerve fibers in the optic nerve. Small hyperopic eyes may have a small retinal surface and smaller optic disc. A deficiency of nerve fibers may be responsible for decreased visual acuity in amblyopic eyes..$^{30,31}$ Some studies have shown that eyes with amblyopia may have smaller optic disc areas than non-amblyopic eyes and healthy control eyes, and subclinical optic disc anomalies may be associated with amblyopia; some did not found any difference. ${ }^{7,29,32}$ Be that as it may, the relationship between amblyopia and disc anomalies is questionable; the recently announced small disc area related to amblyopia may have been brought about by a connection with hyperopia and anisometropia, and not due to a direct causal relationship between small disc area and amblyopia. ${ }^{33}$ The present study found a significant difference between amblyopic and fellow eyes.

These inconsistent findings may be explained in part by the use of different instruments, the relatively small sample sizes, and the lack of population-based controls in all the studies. Yen et $\mathrm{al}^{7}$ hypothesized that the normal postnatal reduction (apoptosis) of retinal ganglion cells is arrested in amblyopia and predicted that this would cause increased RNFL thickness. The arrest of normal postnatal changes would likely result not only in increased RNFL thick- ness but also would affect the normal maturation of the macula, including the movement of Henle's fibers away from the foveola and a decrease in foveal cone-diameter. This would result in increased foveal thickness. Our findings were similar to the Yen's hypothesis. The increased central macular and foveal minimum thickness in amblyopic eyes could account for part of the reduced VA observed. It is not clear whether the change in central macular and foveal minimum thickness preceded the development of amblyopia or occurred afterward.

In conclusion, this study found a slightly thicker central macular region and 6-mm ring area thicknesses and RNFLT in amblyopic eyes compared with normal fellow eyes, using optical coherence tomography. Further research should aim to study the effect of foveal thickness changes on visual acuity in amblyopic children.

Ethics Committee Approval: Bağcllar Training and Research Hospital Clinical Research Ethics Committee approval was obtained. (2016/489).

Conflict of Interest: No.

Funding: No.

Informed Consent: Yes.

\section{REFERENCES}

1. Von Noorden GK, Middleditch PR. Histology of the monkey lateral geniculate nucleus after unilateral lid closure and experimental strabismus: further observations. Invest Ophthalmol 1975;14:674-683.

2. Campos E. Amblyopia. Surv Ophthalmol 1995;40:23-39 https://doi.org/10.1016/S0039-6257(95)80044-1

3. Von Noorden GK. Mechanism of amblyopia. Doc Ophthalmol 1977;34:93.

4. Phillipp W, Mayer W. Investigation of visual field defects in strabismic and anisometropic amblyopes with the Octopus Program G1. Graefes Arch Clin Exp Ophthalmol 1989;227:448-54. https://doi.org/10.1007/BF02172897

5. Mehdorn E. Nasal field defects in strabismic amblyopia. Doc Ophthalmol 1986;45:318-29. https://doi.org/10.1007/978-94-009-4263-9_45

6. Aggarwal DP, Verma G. Static perimetry in the study of amblyopic scotomata. Br J Ophthalmol 1980;64:713-16. https://doi.org/10.1136/bjo.64.9.713

7. Yen MY, Cheng CY, Wang AG. Retinal nerve fiber layer thickness in unilateral amblyopia. Invest Ophthalmol Vis Sci 2004;45:222430. https://doi.org/10.1167/iovs.03-0297

8. Huynh SC, Wang XY, Rochtchina E, Mitchell P. Peripapillary retinal nerve fiber layer thickness in a population of 6-year-old children: findings by optical coherence tomography. Ophthalmology 2006;113:1583-92. https://doi.org/10.1016/j.ophtha.2006.02.067 
9. Robaei D, Rose K, Ojaimi E, Kifley A, Huynh S, Mitchell P. Visual acuity and the causes of visual loss in a population-based sample of 6-year old Australian children. Ophthalmology 2005;112:127582.

https://doi.org/10.1016/j.ophtha.2005.01.052

10. Altintas O, Yuksel N, Ozkan B, Caglar Y. Thickness of the retinal nerve fiber layer, macular thickness, and macular volume in patients with strabismic amblyopia. J Pediatr Ophthalmol Strabismus 2005;42:216-21. https://doi.org/10.3928/01913913-20050701-03

11. Repka MX, Goldenberg-Cohen N, Edwards AR. Retinal nerve fiber layer thickness in amblyopic eyes. Am J Ophthalmol 2006;142:247-51.

https://doi.org/10.1016/j.ajo.2006.02.030

12. Huynh SC, Samarawickrama C, Wang XY, Rochtchina $Y$, Wong TY, Gole GA, Rose KA, Mitchell P. Macular and nerve fiber layer thickness in amblyopia: The Sydney Childhood Eye Study. Ophthalmology 2009;116:1604-9. https://doi.org/10.1016/j.ophtha.2009.03.013

13. Altindag S, Sahin M. Evaluation of the macular thickness by optical coherence tomography in amblyopia. J Clin Exp Invest 2016;7:178-83. https://doi.org/10.5799/ahinjs.01.2016.02.0593

14. Li J, Ji P, Yu M. Meta-analysis of retinal changes in unilateral amblyopia using optical coherence tomography. Eur J Ophthalmol 2015;25:400-9. https://doi.org/10.5301/ejo.5000583

15. Rajavi Z, Sabbaghi H, Behradfar N, Yaseri M, Aghazadeh Amiri M, Faghihi M. Macular Thickness in Moderate to Severe Amblyopia. Korean J Ophthalmol 2018;32:312-8. https://doi.org/10.3341/kjo.2017.0101

16. Dickmann A, Petroni S, Perrotta V, Salerni A, Parrilla R, Aliberti S, Savastano MC, Centra D, Discendenti S, Balestrazzi E. A morphofunctional study of amblyopic eyes with the use of optical coherence tomography and microperimetry. Journal of AAPOS 2011;15:338-341. https://doi.org/10.1016/j.jaapos.2011.03.019

17. Klein R, Klein BE, Linton KL, De Mets DL. The Beaver Dam Eye Study: visual acuity. Ophthalmology 1991;98:1310-5. https://doi.org/10.1016/S0161-6420(91)32137-7

18. Hee MR, Izatt JA, Swanson EA, Huang D, Schuman JS, Lin CP, Puliafito CA, Fujimoto JG. Optical coherence tomography of the human retina. Arch Ophthalmol 1995;113:325-32. https://doi.org/10.1001/archopht.1995.01100030081025

19. Schuman JS, Pedut Kloizman T, Hertzmark E, Hee MR, Wilkins JR, Coker JG, Puliafito CA, Fujimoto JG, Swanson EA. Reproducibility of nerve fiber layer thickness measurements using optical coherence tomography. Ophthalmology 1996;103:1889-98. https://doi.org/10.1016/S0161-6420(96)30410-7

20. Paunescu LA, Schuman JS, Price LL, Stark PC, Beaton S, Ishikawa H, Wollstein G, Fujimoto JG. Reproducibility of nerve fiber thickness, macular thickness, and optic nerve head measurements using StratusOCT. Invest Ophthalmol Vis Sci 2004;45:1716-24. https://doi.org/10.1167/iovs.03-0514
21. Huynh SC, Wang XY, Rochtchina E, Crowston JG, Mitchell P. Distribution of optic disc parameters measured by optical coherence tomography: findings from a population-based study of 6 -year old Australian children. Invest Ophthalmol Vis Sci 2006;47:3276-85. https://doi.org/10.1167/iovs.06-0072

22. Liu H, Zhong L, Zhou X, Jin QZ. Macular abnormality observed by OCT in children with amblyopia failing to achieve normal visual acuity after long-term treatment. J Pediatr Ophthalmol Strabismus 2010;47:17-23. https://doi.org/10.3928/01913913-20091019-06

23. Andalib D, Javadzadeh A, Nabai R, Amizadeh Y. Macular and retinal nerve fiber layer thickness in unilateral anisometropic or strabismic amblyopia. J Pediatr Ophthalmol Strabismus 2013;50:218-21. https://doi.org/10.3928/01913913-20130319-02

24. Doguizi S, Yılmazoglu M, Kızıltoprak H, Sekeroglu MA, Yilmazbas P. Quantitative analysis of retinal microcirculation in children with hyperopic anisometropic amblyopia: an optical coherence tomography angiography study. J AAPOS 2019;-:1.e1-5. https://doi.org/10.1016/j.jaapos.2019.01.017

25. Bozkurt B, Irkec M, Orhan M, Karaagaoglu E. Thickness of the retinal nerve fiber layer in patients with anisometropic and strabismic amblyopia. Strabismus 2003;11:1-7. https://doi.org/10.1076/stra.11.1.1.14091

26. Colen TP, de Faber JT, Lemij HG. Retinal nerve fiber layer thickness in human strabismic amblyopia. Binocul Vis Strabismus Q 2000;15:141-6.

27. Baddini-Caramelli C, Hatanaka M, Polati M, Umino AT, Susanna RJr. Thickness of the retinal nerve fiber layer in amblyopic and normal eyes: A scanning laser polarimetry study. Journal of AAPOS;2001:82-84. https://doi.org/10.1067/mpa.2001.112678

28. Yoon SW, Park WH, Baek SH, Kong SM. Thicknesses of macular retinal layer and peripapillary retinal nerve fiber layer in patients with hyperopic anisometropic amblyopia. Korean J Ophthalmol 2005;19:62-7. https://doi.org/10.3341/kjo.2005.19.1.62

29. Taşkıran Çömez A, Şanal Ulu E, Ekim Y. Retina and Optic Disc Characteristics in Amblyopic and Non-amblyopic Eyes of Patients with Myopic or Hyperopic Anisometropia. Turk J Ophthalmol 2017;47:28-33. https://doi.org/10.4274/tjo.54289

30. Papastathopoulos KI, Jonas JB, Panda-Jonas S. Large optic discs in large eyes, small optic discsin small eyes. Exp Eye Res. $1995 ; 60: 459-461$.

https://doi.org/10.1016/S0014-4835(05)80102-2

31. Lempert P. Optic nerve hypoplasia and small eyes in presumed amblyopia. J AAPOS. 2000;4:258-266. https://doi.org/10.1067/mpa.2000.106963

32. Lempert P. Retinal area and optic disc rim area in amblyopic, fellow, and normal hyperopic eyes: a hypothesis for decreased acuity in amblyopia. Ophthalmology. 2008;115:2259-2261. https://doi.org/10.1016/j.ophtha.2008.07.016

33. Archer SM. Amblyopia? J AAPOS. 2000;4:257. https://doi.org/10.1067/mpa.2000.110552 